\title{
EXPLORING THE TAXONOMY PHASES OF MALIK BADRI'S THINKING PROCESS AMONG STUDENTS ENROLLED IN TAUHIDIC SCIENCE EDUCATION FOR BIOLOGY SUBJECT
}

\author{
MENEROKA TAKSONOMI FASA PROSES BERFIKIR MALIK BADRI \\ DALAM KALANGAN MURID YANG MENGIKUTI PENDIDIKAN SAINS \\ SECARA TAUHIDIK BAGI MATA PELAJARAN BIOLOGI
}

\author{
Zainun Mustafa ${ }^{1}$ \\ Universiti Sains Malaysia. \\ (Email: zainunmustafa@gmail.com / zm12_edu181@student.usm.my) \\ Nooraida Yakob ${ }^{2}$ \\ Universiti Sains Malaysia. \\ (Email: nooraida@usm.my)
}

Received date: $18-06-2019$

Revised date: 01-07-2019

Accepted date: 05-10-2019

Published date: 15-12-2019

To cite this document: Mustafa, Z., \& Yakob, N. (2019). Exploring the Taxonomy Phases of Malik Badri's Thinking Process among Students Enrolled in Tauhidic Science Education for Biology Subject. International Journal of Education, Psychology and Counseling, 4 (33), 0112.

DOI: $10.35631 /$ IJEPC.433001

\begin{abstract}
The taxonomy of the Malik Badri's thinking process phase is a guide for cognitive assessment that has been proposed as an alternative to Bloom's Taxonomy. This taxonomy considers the Islamic worldview to be incorporated into the cognitive evaluation of the Muslims' learning process. This article explored the action-oriented-thinking of a group of students who undergo a unique program inspired by Tauhidic Science concept. The structured interview protocols used in the study was Articulated Thought in Simulated Situation (ATSS) Dilema nutrisi. The ATSS-Dilema nutrisi is an instrument to gauge the goal-oriented thinking based on the Articulated Thought In Simulated Situation (ATSS) procedure. The purpose of this protocol is to explore the cognitive behaviour of 'action-oriented thinking' related to food and dietary practice among students. This study procedure was started with the training protocol and then followed by the ATSS- Dilema nutrisi protocol. Oral responses are transcribed and analyzed until themes are derived. The findings show that based on 108 responses to simulation-related situations, only three of the four phases of the process have been identified namely musyahadah, tadlawuk and tafakur. The highest level of thinking phase which is syuhud is not identified throughout this study.
\end{abstract}

Key words: Thinking Process Phase Taxonomy Malik Badri, ATSS Nutrition Dilemma, Bloom Taxonomy, Science-based Science Education 


\begin{abstract}
Abstrak: Taksonomi fasa proses berfikir Malik Badri merupakan panduan penilaian kognitif yang telah dicadangkan sebagai alternatif kepada Taksonomi Bloom. Taksonomi ini mengambil kira fitrah beragama dalam ukuran kognisi dalam kalangan Muslim. Artikel ini meneroka pemikiran yang berorientasikan tindakan dalam kalangan pelajar yang mengikuti pendidikan sains Biologi secara Tauhidik di sekolah yang tertentu. Instrumen temu bual berstruktur yang digunakan dalam kajian ialah Articulated Thought in Simulated Situation (ATSS) Dilema Nutrisi. ATSS Dilema Nutrisi merupakan protokol temu bual berstruktur yang dibangunkan untuk meneroka perilaku kognitif iaitu 'pemikiran' yang berorientasikan 'tindakan' khususnya berkaitan makanan dan amalan pemakanan. Protokol ini bertujuan untuk meneroka pemikiran yang berorientasikan tindakan dalam kalangan pelajar. Prosedur kajian ini dimulakan dengan protokol latihan dan kemudiannya diikuti Protokol ATSS Dilema Nutrisi. Respon lisan ditranskrib dan dianalisis sehingga menerbitkan tema. Hasil kajian mendapati, berdasarkan 108 respon berkaitan pemikiran, hanya tiga dari empat fasa proses telah dikenal pasti iaitu musyahadah, tadlawuk dan tafakur. Fasa tertinggi iaitu syuhud tidak dapat dikena lpasti.
\end{abstract}

Kata Kunci: Taksonomi Fasa Proses Berfikir Malik Badri, ATSS Dilema Nutrisi, Bloom Taksonomi, Pendidikan Sains berteraskan Tauhid

\title{
Introduction
}

Malaysia education system is developed based on the principles from National Education Philosophy (NEP) 1988. The policy highlighted necessitates nurturing the potential of an individual continuously through the holistic and integrative education system. Relevant to the diverse socio-cultural of a Muslim majority country, NEP upholds the firm belief and submission to God to develop a human capital who has balanced competencies substantiated by four core components: intellectual, spiritual, emotional and physical capacities. The philosophy has been the common ground for all the educational activities since then. To date, the Malaysian Education blueprint 2013-2025 (Mohd. Zaidi, 2016) still revolves around the same philosophy.

Even though the Malaysian education philosophy strength based profoundly in an integrative and holistic approach in the development of four core components of human development, there are loopholes in the Malaysian teaching curricula; especially in testing and evaluating students' performances. Bloom's Taxonomies and the revised version of the same taxonomies have been regarded for a long time as an important guide for educators in the teaching and learning process in Malaysia to evaluate objective-oriented student performances.

From the historical viewpoint, in the 1950s, Benjamin Bloom classifies phases of learning into six discrete categories. The classification is in a hierarchy and known as Bloom's Taxonomy of Educational Objectives. The taxonomies focus on developing thinking ability which involves simple information acquisition to more complex processes (Bloom, 1956). The six sequential cognitive phases are knowledge, comprehension, application, analysis, synthesis, and evaluation. However, the taxonomy was later revised in 2001 by Krathwohl by rearrangement of the order of the phases and chunking them into two larger categories namely High Order Thinking Skills and Low Order Thinking Scale. The primary concern of these two versions of guides is that both of them separate the core values of God-believing worldview from appraising student cognitive competencies. 
Malik Badri (1996) has criticized the cognitive evaluation was based on blurry norms and without consideration of spiritual element. Malik Badri indicts that, the separation of this spiritual aspect in cognitive appraisal resulted in a conflict in the Muslim thinking and reasoning. Based on the existence of the addressed issue, Malik Badri scrutinized the early Muslim scholars of thought, especially Al-Ghazali, Abu Zayd Al Balkhi, Miskawayh, Ibn Taymiyyah and Ibnu Qayyim (Khan, 2015). Malik Badri explores the thinking process as the essence of Islamic spirituality which is based on a person's awareness and recognition of his existence and place in creation. He has identified the contributions of these intellectuals that relate the influence of thinking and cognitive processes in the formation of beliefs, attitudes and behaviours (Malik Badri, 2000, 2016). Malik Badri further explained that the behaviour and attitude are the implication of how one thinks. Consequently, Malik Badri address the importance of a person's thinking which is translated into belief, feelings and actions as the important factor in Muslim education.

Compared to Bloom's Taxonomy, the study on Malik Badri's Thinking Process is still limited. Thus, the aim of this article is to report the finding of a study which attempts to identify the phases of Malik Badri Thinking Process in a group of Muslim students. This study focuses on analysing the articulated thought by the respondents when given specific simulated situations. Thereupon, this study contributes to the empirical evidence towards understanding of Malik Badri Taxonomy as an alternative to the Bloom Taxonomy.

\section{Literature Review}

Tauhidic Science Education is a concept proposed by Khalijah has been shown to have developed the theory as early as 1992 (Wan Mohd. Zahid 1992: Khalijah 1992). Tauhidic Science Education defined as 'the training to nurture the individuals with scientific skill and knowledge within the framework of their position as servants of Allah s.w.t and caliph of Allah s.w.t.' Since then, this concept was promoted and later introduced to 245 teachers from religious school and 'regular' schools in 2008 through a series of seminars and workshops (Khalijah et al., 2011).

Khalijah (2014) explains that the four objectives of the Tauhidic Science Education are to 1) understand the nature of the Al-Qur'an, 2) understand that the scientific method and science process skills through the Al-Qur'an and practical lesson, 3) recognise the greatness of One God through scientific knowledge and scientific process and 4) foster oneself as a responsible servant of Allah s.w.t and the caliph who can possess according to his nature, balance and harmonious with environment. In short, the aspiration in Tauhidic Science Education is to provides the chances for students to understand and positions self as active man according to scientific thinking and Islamic values. This study explores the thinking process of students who have undergone a learning process using the concept of Tauhidic Science Education for Biology subjects. Compared to ideal responses in examination, this study focuses on the realistic responses of students when they have the freedom to choose their action in simulated situation.

From the psychological perspectives, by understanding how the scientific theories operate in the environment, students will be more motivated to learn (Resnick \& Klopfer, 1989). Acknowledging the existing preconceived ideas and its organization, the learning process could be fostered to be meaningful according to the cultural context. In other words, a person will accept the knowledge input if it is in accordance with one's understanding of the self, environment and worldviews. This concept known as 'scientifically compatible worldview' (Cobern, 2015). 
The 'scientifically compatible worldview' proposes that the existing cognitive framework to someone is the cumulative experience which makes ones to accept the theories and understands concepts of science. Thus, the science learning experience does make 'sense' for student to be applied in their daily life. For Biology subjects, 'sense making' are expected to involve scientific literacy in decision-making especially in relation to the content of Biology in matters of everyday life. Such applications for Biology subjects make these Biology subjects more relevant outside the classroom (Himschoot, 2012).

To explore the application of the knowledge in school setting, the Bloom Taxonomy serves as a guide to evaluate the cognitive achievements. The taxonomy was proposed in 1956 by Benjamin Bloom, and reviewed by Tyler who is an expert in the field of educational evaluation in the early development (Forehand, 2012). For nearly 50 years, Bloom Taxonomy widely used to understand student cognitive achievement in school setting (Sockett, 2010, Anderson \& Krathwohl, 2001). The influence of this taxonomy could be noticed in Biology syllabus and lesson plans to create learning outcomes that target not only subject matter but also the depth of learning they want students to achieve, and to then create assessments that accurately measure cognitive ability.

The six-levelled taxonomy (Bloom \& Krathwohl, 1959) are straight forward and started at the lowest level 1 (Knowing). At this level, students should be able remember, retrieve, writing, articulating, labelling, naming, stating, defining, recalling recognize and recall the relevant information, ideas and principles as they have been taught. Then, at level 2 (Understand), the students able to construct meaning from oral, written and graphic messages through interpreting, exemplifying, classifying, summarizing, inferring, comparing, conclude, describe, illustrate and explain. Consequently, when the student represents the information in other forms, execute and implement, show, construct, carry out and using procedure to solve problems, she/he is at the level 3 (Application).

The student cognition is achieving level 4 (Analysis), when they are able to demonstrate the ability to break the information into constituent parts, determining how the part relates to other and to an overall structure or purpose through differentiating, organizing and attributing, distinguish, explain, relate to hypothesis/inference and prove. At level 5 (Synthesis), students produce, hypothesize, awaken, shape, organize, integrate and combine ideas to form a new products, plan or proposal. Finally, student is regarded to achieve the level 6 (Evaluation) in cognitive domain once the students starts to appreciate, value, judge and criticize, reasoning and refute based on standard specified criteria.

In 2001, David Krathwohl and Lorin Anderson published a new revised version to the taxonomy (Anderson \& Krathwohl, 2001). They focused towards active performance of the types of learning involved in each stage of the hierarchy by alteration in language used from nouns to verbs. Besides, the 'Synthesis' was also dropped and 'Create' was moved to the highest level of the domain.

Even though the revised version gained attention among educator, Norillah and Sharifah Sariah (2012) claim that adapting Bloom Learning Taxonomy whether the original or the revised version in the background of Muslim education reflects the desertion of the spiritual aspect in Muslim personal development. Based on this criticism, Norillah and Sharifah Sariah (2012) conducted a comparative analysis to illustrate the uses of Malik Badri Thinking Process Taxonomy versus Bloom Learning Taxonomy in the context of Muslim education. They 
conclude that there is a mismatch in the end goal of the Bloom Learning Taxonomy in the cognitive assessment of a Muslim.

Commenting on Bloom's Taxonomy, the end goal of the taxonomy revolves around the ability to assess the 'good' decision of the material world. However, the ultimate goal in the development of Muslim cognitive not only leads to good judgment either consisting of worldly affairs, but also being able to draw closer to Allah s.w.t as the caliphate and servants to Allah s.w.t (Kamal Hassan, 2010). In fact, the cohesion and the formation of a cognitive dimension with a balanced spiritual in the construction of Muslim personality is the essence of dakwah (Muhammad Nur Abdullah, 2006).

Similar to Bloom's approach, Malik Badri's Thinking Process is in a hierarchy/taxonomy with a clear concept compared to other thinking models. For example, Nordin and Surajudeen (2015) proposed a Muslim-oriented thinking model represented in a cycle is difficult to state the achievement status since it is in a continuous loop. Whereas, Abdul Kadir Arifin (2003) published a hierarchical types-of thinking phase and indicated the 'knowledge of the prophetic' as the highest. Thus, this model also has a drawback to be practiced in schools.

Malik Badri's Taxonomy is developed using Arabic terminology. Hence, in order to prevent confusion especially in the use of the Arabic-derived terminology from the relating-theories rooted in different Muslim intellectuals, this article maintains the original term used by Malik Badri.

This taxonomy was first introduced through his book "Al-Tafakur min al-Musyahadah ila alSyuhud: Dirasah al-Nafsiyah al-Islamiyah". This book is based on the philosophy thought by Ibn Taimiyah supported by Hassan Al-Basri, Al-Ghazali and Ibn Qayyim (Malik Badri, 1996).

The thinking process taxonomy consists of four closely related phases. The first phase is 'musyahadah'. This phase refers to the intellectual activity that interprets empirical information directly through special senses such as hearing, touch and other senses or indirectly through imaginative phenomena and abstract knowledge. Al-Qardawi summarizes this phase as a knowledge of empirical perceptions or of sensory receptions directly (Ansari, 2001; Bokhari, 2000).

The second phase is 'tadlawuk'. This phase involves an expression of admiration through observation and seeing the beauty, strength, privilege, and meticulous of creation with respect to sentiments and feelings. This second phase involves a scientific analysis to understand the structure, function, law in nature and uniformity in the nature of nature. This phase focuses on appreciation the aestatics of the perceived information

Then, the third phase is 'tafakur'. In this phase, the process of thinking is focused to feel the existence of a great God and His attributes. This phase is referred to as contemplation and feeling of submission to the Creator who created everything (Ansari, 2001). Basically, it remarks the perception of the thought that 'feels the existence of God's sovereignty and His high attributes' and acts of worship that are 'subject to the Creator' indicate appreciation of the existence of God takes place and develops in this phase.

In this phase, Malik Badri describes that the capital to think is knowledge that is balanced with fear (tawakal), love and responsibility to God s.w.t. By doing so, one's mind is used to observe 
learning (ibrah and iktibar) obtained through empirical perception and reflection of the past whether good or bad. The process of 'tafakur' is Allah s.w.t.'s commandment as mentions in several verses in the Qur'an through threats, histories, hymns, suggestions, oaths and favours (Malik Badri, 2000).

Tafakur can be performed through conscious thought and remembrance of Allah s.w.t (zikr) (Sidek, 2009). According to Malik Badri (2000), this third phase is the formulation of Hasan Al-Basri's and Al-Ghazali's idea who demanded the completion of zikr activities and thinking continuously as to form virtuous personal strength. The essence of Malik Badri's explanation of this third phase is intended for the creation of a superior personality of the thought process that recognizes the existence of Allah s.w.t or God consciousness.

The fourth and highest phases are 'shuhud' or 'bashirah'. This phase is formed when the process of tafakur becomes habitual through increased frequency of the tafakur process. Al-Qardhawi associates this phase as 'muraqabah' which is an intimacy and intuitive knowledge and is the interpretation of Rasulullah s.a.w towards the term 'ihsan' i.e worshipping Allah s.w.t as though seeing him. Ansari (2001) also analogous this phase as a 'person's attraction to God like a magnet'.

The thinking process phase was proposed by Malik Badri and then progressively reviewed and discussed by several authors. At first, Malik discussed the dilemma of modern psychology with a Muslim's faith and suggested the phases of Muslim thinking. The process of thinking was in detailed explanation with clinical evidences. Based on these details, Al-Ansari (2001) has summarized it in the sequential order. Almost 10 years later, Norillah and Sharifah Sariah (2012) reorganize this phase in taxonomic form so that it can be compared with the Bloom Learning Taxonomy.

Norillah and Sharifah Sariah (2012) states that the Bloom Taxonomy is inclusive in the first and second lowest level of Malik Badri's Thinking Phase. The lowest level is understanding and knowledge, while the second level is evaluation, synthesis, analysis and application. The first and second level is the interpretation of Bloom's Learning Taxonomy, which is thought in the material and physical scope. The third level of tafakur and the fourth, which is spiritual cognition, is the ability to relate to the spiritual aspect.

\section{Research Methodology}

This exploratory research involves collecting data using Articulated Thought in Simulated Situation (ATSS) Dilema nutrisi interview protocol. ATSS Dilema nutrisi is an instrument developed based on Biology syllabus for nutrition topics, food concepts and nutrition practices in Islam and consumerism in Malaysia. This instrument is a structured interview containing two protocols; the training protocol and followed consecutively by the interview protocol. The training protocol aims to familiarize respondents with specific ATSS procedures.

ATSS-Dilema Nutrisi is an instrument to gauge goal-oriented thinking based on the Articulated Thought in Simulated Situation (ATSS) procedures. The instrument is administered in Bahasa Melayu and specifically designed for Muslim youth in Malaysia. The instrument is intended to serve as a guide for a better understanding of the trends in cognitive behaviour of form four science stream students when stimulated to think in various situations related to nutrition and eating habit. ATSS Dilema-Nutrisi focuses on the student's ability to articulate their thoughts in non-exam-nature scenarios. 
The validity and reliability of the instrument are discussed quantitatively and tested in a pilot study. The validity and reliability checking are conducted in-depth using mathematical formulae and software Statistical Package of Social Science version 23 (SPSS 23). Thus, the instrument is corrected and modified according to the expert comments before administrated for data collection.

Example of an interview question:

Anda melihat dalam kesibukan pelanggan yang ramai, banyak sekali lalat diruangan hidangan makanan. Malahan makanan terdedah dan tidak ditutup dengan baik. Anda berjalan masuk kedalam restoran dan mendapati harga makanan yang ditawarkan sangat murah dan ramai sekali pelanggan yang beratur untuk mengikuti promosi tersebut. Apakah yang anda fikirkan?

Example of an interview question: (translated):

You notice in the bustle of customers, there are lots of flies surrounding the food. The food is even exposed and not well-covered. You walk into the restaurant and find that the food prices offered are very cheap and there are so many customers queuing up for the promotion. What do you think about this situation?

The sampling technique used in this study is purposive sampling. The qualitative data are collected from nine respondents. Each of the respondents is provided with 12 simulated situations. Thus, the sum of cases analysed are 108 ( 9 respondent x 12 situations). The selected sample is based on a population framework that is 1) academically gifted students 2) exposed in Tauhidic Science Education for Biology subject for 6 months and 3) a Muslim.

The response has been recorded and transcribed. The unit of analysis of the data is segments or cases. The frequencies of the emerging themes were identified, calculated and analysed using a descriptive statistic. Since the purpose of this study is to explore the thinking of students based on the existing taxonomies, thus, the themes extracted are based on the characteristics of each phase of taxonomies as previously discussed.

\section{Findings}

Based on the 108 transcript responses recorded for exploring the students' thinking phases, only three of the four phases identified were musyahadah, tadlawuk and tafakur only. Meanwhile, the syuhud phase are not found. There are responses which could not be categorized to any of the phase; misunderstanding/ negative response.

\begin{tabular}{lll}
\hline Phase / themes & Characteristics of articulation of thought & $\begin{array}{l}\text { Frequency } \\
\text { percentage }\end{array}$ \\
\hline Tafakur & $\begin{array}{l}\text { Able to show God-Consciousness and thinks } \\
\text { logically, scientifically and able to demonstrate }\end{array}$ & $41.7 \%$ \\
& science literacy in a simulated situation.
\end{tabular}

or

Able to show God-Consciousness and but limited ability to think logically, scientifically and to demonstrate science literacy in a simulated situation. 
Tadlawuk Able to think logically, scientifically and able to 21 demonstrate science literacy in a simulated $19.4 \%$ situation but limited in showing GodConsciousness

Musyahadah Able to think based on sensory acquisition and nonlearning experiences

22

Misunderstanding/ Unable to demonstrate scientific literacy and/or 20 negative response God-Consciousness.

No response, silent or respondent refuses to answer

Exclude to Tafakur, Tadlawuk, Musyahadah phase.

From the acquired data, respondents are at the musyahadah phase when they articulate their thoughts based on acquisition of sensory and non-learning experiences. This phase can be identified when respondents associate the situation with allergies, favours, parental influence, biased perspectives, emotions and advertising influences. This is the lowest phase of thinking process, according to Malik Badri. In this study, $20.4 \%$ of responses are categorized as musyahadah.

Meanwhile, $19.4 \%$ of responses are at the tadlawuk phase. The thinking process is at the tadlawuk phase when they demonstrate the ability to think logically and scientifically based on their learning experiences. At this phase, the respondents demonstrate the ability to link the phenomenon in the situation in terms of context and concept of scientific knowledge and using logical connectors such as conditional implications, causal relationships, inferences, inductive and deductive generalizations, predicting based on conditions, and process cues and information from the situation before a sound articulation is made. The finding shows that the respondents are able to show rationality and scientific literacy when linking the situation contextually to existing knowledge.

According to Malik Badri, at the tafakur phase, the inclusion of divinity aspect in the thinking process can be found. In this study, $41.7 \%$ of the responses are categorized as tafakur. In most cases, the responses enriched with terms derived from Arabic Language or Al-Quran. Usually respondents explain the situation by associating with Islamic law either the concept of halal, haram, sunnah or dubious. Sometimes, the responses extend towards the metaphysical reward such as heaven and hell fire. Responses in this category feature with religious-science coincidence. However, there are also respondents who relate the divine aspect without explaining the scientific knowledge, scientific thinking or logical connectors.

Finally, the Shuhud phase is achieved when the consciousness of God has become a practice of self-reflection. In this study, the shuhud phase is not identified. Based on the study of 108 transcripts of respondents exposed with Tauhidic science education, the tafakur phase is found at most, continued by musyahadah and least is tadlawuk. 


\section{Discussion}

From the findings of this study, three phases of the thinking process are explored. The existence of these three phases shows an indication that the outcome of science teaching and learning has been enriched by opening the boundaries of the discipline of science-religion. The data indicates that, when the science lesson is dynamic by interlinking religious realm (Islamic Worldview) with scientific knowledge, the student shows variation in their thinking phase. Students are able to express their thought from different perspectives and allowed to acknowledge their preference in daily decision making. The variation in thinking phase is the sign of students are not indoctrinated during the lesson

Similar to the finding of this study, the variation in thinking amongst Muslim students in Malaysia is detailed in a study by Kamisah Osman, Lilia Halim, and Zanaton Ikhsan (2017). According to them, the openness in the acceptance of knowledge among Muslim students is very much related to Quran proposition and government policies that accept the diversity of races and religions in Malaysia. They continued, even though if the learned knowledge is contradictory to the original belief system or pre-conception, the student still has courageous craving to seek true knowledge when one is educated with high-level thinking and exhibits Islamic-Science interaction. The similar idea discussed by the studies from other countries i.e Deniz, Donnelly, and Yilmaz (2008) and Mansour (2008). But Hanley (2012) shows contradicting results when students are in a secular system.

Based on the analysis, $37.0 \%$ of respondents showed the ability to tafakur and $19.4 \%$ at tadlawuk thinking phase. Both of these phase shows that the student tried to execute the scientific knowledge in their daily life scenarios. The student shows the ability to draw rational thinking and apply scientific knowledge in the real-life context. Thus, they were able to demonstrate the decent scientific literacy by giving the sound reasoning based on knowledge and identify clues to be considered upon deciding the action to be taken.

Nagappan (2001) has explained that the ability of a student to understand some issues scientifically requires not only content knowledge, but more than that is the flexibility to discuss an issue in context. In this study, the student shows the ability to use scientific knowledge, identify problems and draw conclusions based on scientific thinking and weigh their worldview and other aspects when they are in the simulated situations. The findings of this study are complying with the claim that education that integrates religion in education is actively proven to form a better understanding of complex situations (Poulter \& Kallioniemi, 2017; Safrijal, Abdul Halim, \& Mustanir, 2013).

Other than that, it is noticeable that all the responses are relatively simple. The stout simplicity without detailed scientific mechanism or process was frequently found through this study. Even though it was surprising to find these responses among the science stream students sampled in this study, the verbal responses were particularly relevant with the cognitive maturity and belief systems of the students. According to 'Piaget Stages of Cognitive Development', the 16-yearold begins to develop abstract thinking involving logic and scientific thinking known as 'concrete operational level' (Wadsworth, 1971; Giedd, 2015; Kalman, 2018; Lay Yoon Fah, 2009). Indeed, according to the 'Fowler Theory of Faith Development', students around this age are having internal conflict in building self-identity related to their worldview (Fowler \& Levin, 1984). 
Consequently, to note that the students articulated their thoughts in a concise and conclusive manner is theoretically relevant. This can be detected throughout the responses in this study. Even after six months of acquiring a Tauhidic-based-science Education, the student has limited critical thinking ability to the respect of cognitive maturity and development of one's worldview. From the overall finding, the student links the context and concept by the means of logic preposition and rational such as identify observation and symbols, conditional implication, direct relevance and deductive conclusions when responding in a simulated situation.

It can be explained based on the population frame of the study which is a group of in pure science stream students. A study by Kamisah Osman et al. (2017), which compares critical thinking among students in art stream and science stream student, outlined that the science stream students are more concerned with rational arguments (reason). In another study, Lay Yoon Fah (2009) explains that the ability to think logically is also often associated with the ability to understand abstracts in science subjects exhibited through examination data. It is the result of the way students were trained with logic and scientific thinking formed in science/mathematical subjects (Byers, 2010; Mohd Syahmir Alias, 2014). As students have good understanding in these subjects, the students' ability to think in rational, scientific and logical states has shown that the way students apply science is not only from the perspective of the subject matter but also thinking skills as well. Thus, this study discovers that the science stream student of age 16 are able contemplate the scientific literacy and Islamic worldview in daily life.

\section{Conclusion}

This study concludes that three out of four phases of the Thinking Processes of Malik Badri have been identified as musyahadah, tadlawuk and tafakur. The shuhud phase cannot be identified as all respondents show different thinking phase based on the simulated situation.

The students demonstrated independent thinking without doctrinal, open, diverse views but tried to give a rational response to their current cognitive and faith developmental stages. According to the Tauhidic Science Education concept, the faculty of reasoning and faith have been raised to be aware of the relationship with Allah s.w.t., man and nature (Mohd Yusof, 2014).

The most important aspect to be highlighted from this study is the practical use of Malik Badri's Thinking Process Phase as an assessment guide for Muslim's Education. From the study, the assessment should be conducted by oral to avoid student to respond according to the answering schemes. The study also shows that the ability of students who are exposed with Tauhidicscience education considers science fact and comply scientific thinking by acknowledging their religious worldview in their decision making.

\section{References}

Anderson, L., \& Krathwohl, D. (2001). A taxanomy for learning, teaching and assessing: A revision of Bloom taxanomy of educational objectives. Addison-Wesley.

Abdul Kadir Arifin. (2003). Kesan pendekatan penghayatan islam ter hadap pemikiran peringkat tinggi di kalangan pelajar tingkatan 2 (Tesis PhD). Universiti Sains Malaysia.

Ansari, Z. A. (2001). Contemplation: An Islamic psychospiritual study. Intelectual Discourse, 9(2), 219-230. 
Bloom, B. S., \& Krathwohl., D. R. (1959). Taxonomy of educational objectives: The classification of educational goals (Vol. 1). New York: Longmans.

Bokhari, K. A. (2000). Contemplation: An Islamic psychospiritual study. The American Journal of Islamic Social Sciences, 19(128-131), 4.

Byers, W. (2010). How mathematicians thinking: Using ambiguity, contradiction, and paradox to create mathematics. New Jersey: Princeton University Press.

Cobern, W. W. (1989). World view theory and science education research: Fundamental epistemological structure as a critical factor in science learning and attitude development. Kertas kerja dibentangkan di Annual Meeting of The National Association for Research in Science Teaching, San Francisco, CA.

Dani Asmadi Ibrahim, \& Kamisah Osman. (2011). Kemahiran berfikir aras tinggi, pengajaran tajuk model atom dan pencapaian objektif kursus kimia. Kertas kerja dibentangkan di Prosiding Seminar Majlis Dekan-Dekan Pendidikan IPTA, Serdang.

Deniz, H., Donnelly, L. A., \& Yilmaz, I. (2008). Exploring the factors related to acceptance of evolutionary theory among Turkish preservice Biology teachers: toward a more informative conceptual ecology for Biological evolution. Journal of Research in Science Teaching, 45(4), 420-443.

Fah, Lay Foon. (2009). Logical thinking abilities among form 4 students in the interior division of Sabah, Malaysia. Journal of Science and Mathematics, 32(2), 161-187.

Forehand, M. (2012). Bloom's Taxonomy. University of Georgia.

Giedd, J. N. (2015). The amazing teen brains. Neuroscience, 312, 32-37.

Hanley, P. (2012). The inter-relationship of science and religious education in a cultural context: teaching the origin of life (Tesis Phd). University of York.

Himschoot, A. R. (2012). Student perception of relevance of Biology content to everyday life: A study in higher education in Biology course. Capella University, Digital Commons. Dimuat turun daripada http://digitalcommons.olivet.edu/biol_facp/2

Kalman, C. S. (2018). Intelectual development and psychological types (Vol. 16). Cham: Springer.

Kamisah Osman, Lilia Halim, \& Zanaton Ikhsan. (2017). The critical thinking attitudinal pofile of some malaysian secondary students: A reflection of scientific attitudes. Journal of Science and Mathematics Education in S.E Asia, 26(2), 143-167.

Kementerian Pelajaran Malaysia. (2012). Laporan Awal pelan induk pembangunan pendidikan 2013-2025. Dimuat turun daripada www.moe.gov.my/index/php/my/dasar/pelanpembangunan-pendidikan-malaysia-2013-2025.

Khalijah Mohd. Salleh (1992). Pemasyarakatan Sains: Satu proses evolusi spontan atau perencanaan. In O. Mohd Yusof (Ed.), Siri Wacana Sejarah dan Falsafah Sains Jilid 1 (pp. 50-59). Kuala Lumpur: Dewan Bahasa dan Pustaka.

Khalijah Mohd. Salleh, Mohd Yusof, O., Shadidan, R., Jawiah Dakir, Abdul Halim Tamuri, Nor Hayati, A., . . . Mastura, B. (2011). Teachers' concerns, perception and acceptance toward tauhidic science education. Kyoto Bulletin of Islamic Area Studies, 41\&2(March 2011), 124-155.

Khalijah Mohd. Salleh (2014). Sains tauhidik dan implikasi terhadap pendidikan. dalam Khalijah Mohd. Salleh (Ed.), Pendidikan Sains Berteraskan Tauhid. Bangi: Penerbit UKM.

Khan, R. K. A. W. (2015). An interview with Profesor Malik Badri about his contribution to the Islamisation of psychology. Intelectual Discourse, 23(1), 159-172.

Malik Badri. (1996). Tafakur: perspektif psikologi Islam (U. S. Husnan, Terj.). Bandung: Penerbit PT Remaja Rosdakarya. 
Malik Badri. (2000). Contemplation: An Islamic psychospiritual study. Kuala lumpur: Madeena Books.

Malik Badri. (2016). The dilema of Muslim psychologist. Selangor: Islamic Book Trust.

Mansour, N. (2008). Religious belief, a hidden variabel in the performance of science teacher in the classrooms. European Educational Research Journal, 7(4), 557-565

Mohd. Kamal Hassan. (2010). A Return to the Quranic paradigm of development and integrated knowledge: The ulul al-bab model. Intelectual Discourse, 18(2), 183-120.

Mohd Syahmir Alias. (2014). Konsep saintifik dalam kaedah penyelidikan berteraskan Islam: analisis pemikiran Ibnu Haytham (Tesis Master). Universiti Sains Malaysia.

Mohd Yusof, O. (2014a). Islamic science (tawhidic): toward sustainable development. Kyoto Bulletin of Islamic Area Studies, 7(Mac), 110-123.

Mohd Zaidi Ismail. (2016). Islam \& higher order thinking: An overview. Kuala Lumpur: Penerbit IKIM.

Muhammad Nur Abdullah Hafiz Suaid. (2006). Didik anak cara rasululllah s.a.w. . Kuala Lumpur: Klang Book Center.

Nagappan, R. (2001). The teaching of higher-order thinking skills in Malaysia. Journal of Southeast Asian Education, 2(1), 42-65.

Norfadelah Nordin \& Ahmad Tijani Surajudeen. (2015). Islamic theoritical model for critical thinking in teaching and learning of Islamic education. GSE E-Journal of Education, 3, 34-44.

Norillah Abdullah, \& Sharifah Sariah Syed Hassan. (2012). Comparative Analysis between Bloom's and Malik Badri's taxanomies of thinking process. Dinive Felsei Metinler, 1(8), 55-66.

Poulter, S., \& Kallioniemi, A. (2017). Preparing for the world of diverse worldviews: prental and school stakeholder views on integrative worldview education in finnish context. British Journal of Religious Education, 5(1), 75-84. doi: 10.1080/01416200.217.1292211

Resnick L.B \& Klopfer, L.E. (1989) Toward the Thinking Curriculum: Current Cognitive Research. ASCD Yearbook. Association for Supervision and Curriculum Development, Alexandria, Va. ISBN-0-87120-156-9; ISSN-1042-9018

Safrijal, Abdul Halim, \& Mustanir. (2013). Model pembelajaran inkuiri terinternalisasi ayatayat al-Quran untuk meningkatkan pemahaman konsep larutan penyangga dan karater Islami siswa. Jurnal Pendidikan Sains Indonesia, 3(1), 195-206.

Socket, H. (2010). Bloom Taxonomy: A philosophical critique. Cambridge Journal of Education, 1, 16-25. doi: 10.1080/03057647100101103

Sidek Baba. (2009). Zikir dan dikir. Kuala Lumpur, Malaysia: Dewan Bahasa dan Pustaka.

Wadsworth, B. J. (1971). Piaget's Theory of cognitive development, Foundation of constructism (5th Edition ed.). UK: Pearson.

Wan Mohd. Zahid Wan Noordin (1992). Arah Aliran pendidikan sains dalam konteks reformasi pendidikan. Dalam Mohd Yusof Hj. Othman \& Khalijah Mohd Salleh (Eds.), Pendidikan tinggi sains ke arah reformasi pendidikan. Kuala Lumpur: Dewan Bahasa Pustaka. 